\title{
Association of Hypovitaminosis D with Hypertensive Disorder of Pregnancy
}

\author{
Mehwish llyas ${ }^{1}$, Sardar Muhammad Alfareed Zafar², Maryam Javed³, Muhammad Azeem Mughal ${ }^{4}$ \\ 1,2,3Department of Gynecology \& Obstetrics, Lahore General Hospital, Lahore-Pakistan, 4 Kidney \& Transplantation Department, Pakistan Kidney and Liver Institute Lahore-Pakistan
}

\begin{abstract}
Background: Pregnancy related hypertensive disorders have devastating outcome of pregnancy and cause many obstetrical complications during or after pregnancy. Hypovitaminosis $D$ has been observed in many pregnant females having pregnancy induced hypertension. Study Design: Case control study. Settings: Department of Obstetrics \& Gynecology, Lahore General Hospital, Lahore-Pakistan. Duration: 3 months from January 01, to March 30, 2019. Methodology: This Case control study was conducted at Department of Obstetrics \& Gynaecology, for 6 months. Sample size of 100 patients were enrolled in the study through Non-Probability, Consecutive Sampling. Patients of age 18-40years, presented $>24$ weeks of pregnancy were included Then blood sample was taken and vitamin $D$ level was noted. If level $<20 \mathrm{ng} / \mathrm{ml}$, then hypovitaminosis $D$ was labeled. Odds ratio was calculated and if OR>1, then significant association was considered. Results: The mean age of cases was 26.08 $\pm 4.29 y e a r s$ and mean age of controls was $29.84 \pm 2.96$ years. The mean gestational age of cases was $32.58 \pm 9.63$ weeks and controls presented at $36.71 \pm 10.11$ weeks. Mean serum vitamin D level was $24.9 \pm 7.72 \mathrm{ng} / \mathrm{ml}$ among cases while $39.07 \pm 11.14 \mathrm{ng} / \mathrm{ml}$ among controls. The difference was significant $(p<0.0001)$. The hypovitaminosis D was observed in $43(86 \%)$ cases while in $10(20 \%)$ controls. The odds ratio was calculated as $24.57(5 \% \mathrm{Cl}: 8.534-70.745$, $p<0.0001)$, which showed significant association of hypovitaminosis $D$ with hypertensive disorder of pregnancy. Conclusion: There is significant association of hypovitaminosis $\mathrm{D}$ detected with preeclampsia or pregnancy induced hypertension in our study.
\end{abstract}

Keywords: Vitamin D deficiency, Hypovitaminosis D, Preeclampsia, Pregnancy induced hypertension, Blood pressure, Proteinuria.

Corresponding Author

Submitted for Publication: 11-05-2020

Dr. Mehwish llyas, Senior Registrar, Department of Gynecology \& Obstetrics, Lahore General Hospital, Lahore-Pakistan

Email: aimaan85@hotmail.com

Citation: llyas M, Zafar SMA, Javed M, Mughal MA. Association of Hypovitaminosis D with Hypertensive Disorder of Pregnancy. APMC 2020;14(3):241-4.

\section{DOI: $10.29054 / A P M C / 2020.932$}

\section{INTRODUCTION}

Preeclampsia is still one of the major causes of maternal mortality in developed countries with an incidence of $15 \%-20 \%{ }^{1}$ In Pakistan, preeclampsia was present in $21 \%$ pregnancies. ${ }^{2}$ The prevalence of vitamin $D$ insufficiency ranges from 9.3$41.4 \%$, while vitamin $D$ deficiency ranged $22.7-90.3 \%$ in pregnant females. ${ }^{3}$ Supplementation with a balanced protein and energy diet does not appear to reduce the risk of preeclampsia. Further, there is no evidence that changing salt intake has an effect. ${ }^{4}$ Supplementation with antioxidants such as vitamin $C, D$ and $E$ has no effect on pre-eclampsia incidence therefore, supplementation with vitamins $C, E$, and $D$ is not recommended for reducing the risk of pre-eclampsia. ${ }^{4}$

Vitamins are chemicals that are needed by your body for good health. They are vital for everyone and ensure that body works well, is able to fight illness and heal well. Vitamin D deficiency during pregnancy has been linked with a number of serious short- and long-term health problems in offspring, including impaired growth, skeletal problems, type 1 diabetes, asthma, and schizophrenia. Yet few investigators have explored the role of maternal vitamin D status in adverse pregnancy outcomes. ${ }^{5}$ Vitamin $D$ deficiency is highly prevalent in women of reproductive age and in pregnant mothers. ${ }^{6}$ If proven effective, the population level benefits of vitamin $D$ supplementation would be substantial and likely to impact the long-term health of offspring. ${ }^{7}$ The association between maternal vitamin $D$ supplementation and status with the risk of preeclampsia was consistent across different types of studies, with evidence for benefits in prospective observational studies as well as in clinical trials. Two recent meta-analyses of observational studies also support an association between maternal serum $25(\mathrm{OH}) \mathrm{D}$ levels and preeclampsia. ${ }^{8,9}$

The aim of the study is to determine the association of hypovitaminosis $D$ with hypertensive disorder of pregnancy in females presenting in third trimester. It has been observed that in literature that there is significant association of hypovitaminosis $\mathrm{D}$ with hypertensive disorder of pregnancy and preeclampsia is a hazardous complication of pregnancy which may lead to severe morbidities and mortality of pregnant female as well as the fetus. With changing lifestyle and less screening of vitamin $D$ in routine increases the chances of hypertensive disorder of pregnancy and preeclampsia which lead to complications of pregnancy. So, we want to conduct this study to attain the local evidence and implement the screening of pregnant females for vitamin $D$ level in order to prevent hypertensive disorder of pregnancy / preeclampsia.

The objective of the study was to determine the association of hypovitaminosis $D$ with hypertensive disorder of pregnancy in females presenting in third trimester.

\section{METHODOLOGY}

Study Design: Case control study.

Settings: Department of Obstetrics \& Gynecology, Lahore General Hospital, Lahore-Pakistan. 
Duration: 3 months from January 01, to March 30, 2019.

Sample Technique: Non-Probability, Consecutive Sampling. Sample Size: Data of 100 females is calculated with $95 \%$ confidence level, $8.5 \%$ margin of error and taking expected percentage of hypovitaminosis $D$ i.e. $22.7 \%$ in pregnancy in third trimester.

Inclusion Criteria: Patients of age 18-40years, presented $>24$ weeks of pregnancy were included. Cases were those females who had pregnancy induced hypertension $(B P \geq 140 / 90 \mathrm{mmHg})$ or preeclampsia $(\mathrm{BP} \geq 140 / 900 \mathrm{mmHg}$ along with proteinuria $\geq+1$ on dipstick method).

Exclusion Criteria: Controls were the females without hypertension. Chronic conditions including diabetes, chronic hypertension, renal dysfunction, bleeding disorders, females already taking vitamin supplements, anemia were excluded.

Data Collection Procedure: 100 patients fulfilling the abovementioned inclusion criteria were enrolled in this study from OPD. Informed consent was obtained and patient demographic information was recorded. Then blood pressure was noted at presentational and proteinuria was assessed by using dipstick method. Patients were divided in two groups on the basis of blood pressure i.e. cases with hypertension and controls with normal blood pressure. Then blood sample was taken through a $5 \mathrm{cc}$ disposable syringe and sent to the laboratory of the hospital of assessment of vitamin D level. Reports were assessed and vitamin D level was noted. If level $<20 \mathrm{ng} / \mathrm{ml}$, then hypovitaminosis $D$ was labeled. Females with hypovitaminosis $D$ were managed as per standard protocols. Data was recorded on proforma and analyzed by using SPSS version 22 . Odds ratio was calculated and if $O R>1$, then significant association was considered.

\section{RESULTS}

The mean age of cases was $26.08 \pm 4.29$ years and mean age of controls was $29.84 \pm 2.96$ years. The mean gestational age of cases was $32.58 \pm 9.63$ weeks and controls presented at $36.71 \pm 10.11$ weeks. There were $23(46 \%)$ primigravida, 27 $(54 \%)$ multigravida (1-4) and $0(0 \%)$ grand multigravida among cases while $14(28 \%)$ primigravida, 34 (68\%) multigravida (1-4) and $2(4 \%)$ grand multigravida among controls. Among cases, $24(48 \%)$ were primiparous and $26(52 \%)$ were multiparous while among controls, $14(28 \%)$ were primiparous and $36(72 \%)$ were multiparous. Table 1

Table 1: Demographics of patients

\begin{tabular}{|c|c|c|c|}
\hline & \multicolumn{2}{|c|}{ Group } \\
\hline & & Case & Control \\
\hline \multicolumn{2}{|l|}{$\mathrm{n}$} & 50 & 50 \\
\hline \multicolumn{2}{|c|}{ Age (yeas) } & $26.08 \pm 4.29$ & $29.84 \pm 2.96$ \\
\hline \multicolumn{2}{|c|}{ Gestational age (weeks) } & $32.58 \pm 9.63$ & $36.71 \pm 10.11$ \\
\hline Gravida & \begin{tabular}{|l|} 
Primigravida \\
Multipara \\
Grand multipara
\end{tabular} & $\begin{array}{c}23(46 \%) \\
27(54 \%) \\
0(0 \%)\end{array}$ & $\begin{array}{c}14(28 \%) \\
34(68 \%) \\
2(4 \%)\end{array}$ \\
\hline Parity & $\begin{array}{l}\text { Primiparous } \\
\text { Parity 1-3 }\end{array}$ & $\begin{array}{l}24(48 \%) \\
26(52 \%)\end{array}$ & $\begin{array}{l}14(28 \%) \\
36(72 \%)\end{array}$ \\
\hline
\end{tabular}

The mean SBP of cases was $166.6 \pm 22.78 \mathrm{mmHg}$ while $115.20 \pm 9.53 \mathrm{mmHg}$ for controls. The mean DBP of cases was $102.8 \pm 8.27 \mathrm{mmHg}$ while $72.8 \pm 6.07 \mathrm{mmHg}$ for controls. Among cases, proteinuria was $1+$ in $4(8 \%)$ cases, $2+$ in $23(46 \%)$ cases, $3+$ in $12(24 \%)$ cases while nil in $11(22 \%)$ cases. Among controls, proteinuria was nil in all cases $(100 \%)$. Among cases, pregnancy induced hypertension was observed in $11(22 \%)$ cases while $39(78 \%)$ had preeclampsia. Mean serum vitamin D level was $24.9 \pm 7.72 \mathrm{ng} / \mathrm{ml}$ among cases while $39.07 \pm 11.14 \mathrm{ng} / \mathrm{ml}$ among controls. The difference was significant $(p<0.0001)$. Table 2

Table 2: Hemodynamics of patients

\begin{tabular}{|c|c|c|}
\hline & \multicolumn{2}{|c|}{ Group } \\
\hline & Cases & Control \\
\hline $\mathbf{n}$ & 50 & 50 \\
\hline \multicolumn{3}{|l|}{ Blood pressure (mmHg) } \\
\hline SBP & $166.6 \pm 22.78$ & $115.20 \pm 9.53$ \\
\hline DBP & $102.8 \pm 8.27$ & $72.80 \pm 6.07$ \\
\hline $\begin{array}{l}\text { Proteinuria } \\
+ \\
++ \\
++ \\
\text { Nil }\end{array}$ & $\begin{array}{c}4(8 \%) \\
23(46 \%) \\
12(24 \%) \\
11(22 \%)\end{array}$ & $\begin{array}{c}0(0 \%) \\
0(0 \%) \\
0(0 \%) \\
50(100 \%)\end{array}$ \\
\hline $\begin{array}{lr}\text { Type of } & \text { hypertensive } \\
\text { disorder } & \\
\text { Pregnancy } & \text { induced } \\
\text { hypertension } & \\
\text { Preeclampsia } & \\
\end{array}$ & $\begin{array}{l}11(22 \%) \\
39(78 \%)\end{array}$ & Nil \\
\hline $\begin{array}{l}\text { Serum vitamin D level } \\
(\mathrm{ng} / \mathrm{ml})\end{array}$ & $24.9 \pm 7.72$ & $39.07 \pm 11.14^{*}$ \\
\hline
\end{tabular}

${ }^{*}=p$-value $<0.0001$ (Significant)

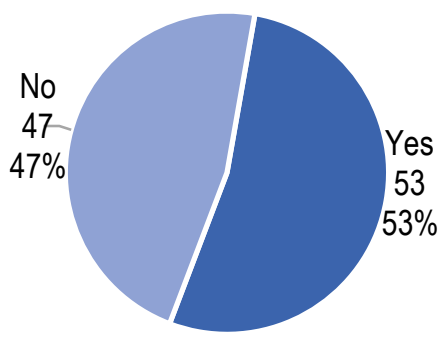

$$
\text { - Yes } \square \text { No }
$$

Fig 1: Hypovitaminosis D

The hypovitaminosis $\mathrm{D}$ was observed in $43(86 \%)$ cases while in $10(20 \%)$ controls. The odds ratio was calculated as 24.57 (5\% Cl: $8.534-70.745, p<0.0001)$, which showed significant association of hypovitaminosis $D$ with hypertensive disorder of pregnancy. Table 3 
Table 3: Association of hypertensive disorder of pregnancy with hypovitaminosis D

\begin{tabular}{|c|c|c|}
\hline \multirow{2}{*}{ Hypovitaminosis D } & \multicolumn{2}{|c|}{ Group } \\
\cline { 2 - 3 } & Case & Control \\
\hline Yes & $43(86 \%)$ & $10(20 \%)$ \\
\hline No & $7(14 \%)$ & $40(80 \%)$ \\
\hline Total & $50(100 \%$ & $50(100 \%)$ \\
\hline
\end{tabular}

Odds ration $=24.57(95 \% \mathrm{Cl}: 8.534-70.745, \mathrm{p}$-value $<0.0001)$

\section{DISCUSSION}

The exact mechanism of how preeclampsia worsen maternal and fetal outcome remains to be elucidated. Uncontrolled inflammation, typical of preeclampsia, might be related to the development of intrauterine pathologies. ${ }^{10}$

Risk factors for pre-eclampsia include obesity, prior hypertension, older age, and diabetes mellitus. It is also more frequent in a woman's first pregnancy and if she is carrying twins. The underlying mechanism involves abnormal formation of blood vessels in the placenta amongst other factors. Most cases are diagnosed before delivery.

Rarely, pre-eclampsia may begin in the period after delivery. While historically both high blood pressure and protein in the urine were required to make the diagnosis, some definitions also include those with hypertension and any associated organ dysfunction. Blood pressure is defined as high when it is greater than $140 \mathrm{mmHg}$ systolic or $90 \mathrm{mmHg}$ diastolic at two separate times, more than four hours apart in a woman after twenty weeks of pregnancy. Pre-eclampsia is routinely screened for during prenatal care. ${ }^{11-14}$

In our study, the hypovitaminosis D was observed in $43(86 \%)$ cases while in $10(20 \%)$ controls. The odds ratio was calculated as $24.57(5 \% \mathrm{Cl}: 8.534-70.745, \mathrm{p}<0.0001)$, which showed significant association of hypovitaminosis $D$ with hypertensive disorder of pregnancy. In a study by Mere wood et al, the risk of preeclampsia was 5 -fold increased among women with $25(\mathrm{OH}) \mathrm{D}$ levels below $15 \mathrm{ng} / \mathrm{mL}$ at a pregnancy duration of up to 22 weeks. ${ }^{15}$ Similarly, Powe et al. reported that first-trimester $25(\mathrm{OH}) \mathrm{D}$ levels of less than $15 \mathrm{ng} / \mathrm{mL}$ were related to the development of preeclampsia. ${ }^{16}$ In a case-control study, women with early-onset (before 34 weeks) severe preeclampsia displayed lower serum 25(OH)D levels (median $18 \mathrm{ng} / \mathrm{mL}, I Q R$ 13-31 $\mathrm{ng} / \mathrm{mL}$ ) than did healthy controls (median 32, IQR 20-44 $\mathrm{ng} / \mathrm{mL}){ }^{17}$

One study has reported that there was a significant increase in the risk of pre-eclampsia among those with vitamin $\mathrm{D}(25(\mathrm{OH}) \mathrm{D})$ level $<50 \mathrm{nmol} / \mathrm{l}$ compared with those without at $24-26$ weeks of gestation $(8.1 \%$ versus $2.5 \%, P=0.001) .{ }^{18}$ One more study has reported that there was a significant increase in the risk of preeclampsia among those with vitamin D $(25(\mathrm{OH}) \mathrm{D})$ level $<50 \mathrm{nmol} / /$ compared with those without at 24-26 weeks of gestation $(58.9 \%$ versus $33.8 \%, P=0.001) .{ }^{17}$ But another study reported that there was an insignificant increase in the risk of pre-eclampsia among those with vitamin $\mathrm{D}(25(\mathrm{OH}) \mathrm{D})$ level
$<50 \mathrm{nmol} / \mathrm{l}$ compared with those without at 24-26 weeks of gestation $(1.67 \%$ versus $1.2 \%, P=0.6947) .{ }^{19}$

A new study finds that women who develop severe preeclampsia tend to have lower blood levels of vitamin $D$ than healthy pregnant women raising the possibility that the vitamin plays a role in the complication. Preeclampsia rates are elevated during winter months, when sunlight-dependent $25(\mathrm{OH}) \mathrm{D}$ productions are reduced. Vitamin $\mathrm{D}$ supplementation reduces preeclampsia risk, compared to unsupplemented controls. ${ }^{20}$

Two clinical trials support a potential role of vitamin $D$ in the prevention of preeclampsia, although neither of these treated with vitamin D supplements alone. In an uncontrolled trial, supplementation with a multivitamin/mineral supplement and halibut liver oil (containing $900 \mathrm{IU} / \mathrm{d}$ vitamin D) provided at $20 \mathrm{wk}$ gestation reduced the odds of preeclampsia by $32 \%(95 \% \mathrm{Cl}$, $11-47 \%$ ). Vitamin D supplementation in early pregnancy should be explored for preventing preeclampsia and promoting neonatal well-being. ${ }^{21}$

Two clinical trials support a potential role of vitamin $D$ in the prevention of preeclampsia, although neither of these treated with vitamin $\mathrm{D}$ supplements alone. In an uncontrolled trial, supplementation with a multivitamin/mineral supplement and halibut liver oil (containing $900 \mathrm{IU} / \mathrm{d}$ vitamin D) provided at $20 \mathrm{wk}$ gestation reduced the odds of preeclampsia by $32 \%(95 \% \mathrm{Cl}$, $11-47 \%$ ). Vitamin D supplementation in early pregnancy should be explored for preventing preeclampsia and promoting neonatal well-being. ${ }^{21}$

\section{CONCLUSION}

Though this study, we found significant association of hypovitaminosis $D$ detected with preeclampsia or pregnancy induced hypertension. Now, we have got the local evidence and now we recommend the females for regular antenatal check-up during pregnancy and screening for vitamin $\mathrm{D}$ levels in order to balance vitamin $D$ level in blood and prevent preeclampsia 0 hypertensive disorders in pregnancy.

\section{LIMITATIONS}

Study was carried out on hundred females; fifty in each group. However, authenticity of results can improve with larger sample size and more findings can be elaborated. Only one vitamin level was checked in this study, but not the other vitamins during pregnancy which may also associated with preeclampsia. Also females were not followed-up for prolonged time till delivery, as that was not part of study and obstetrical outcome with Hypovitaminosis D was also not observed.

\section{SUGGESTIONS / RECOMMENDATIONS}

Further studies can be done on larger sample size to obtain more authentic results. Other vitamins should also be screened during pregnancy in order to find the association of preeclampsia with other vitamins as well. Females with Hypovitaminosis $D$ can be followed-up for prolonged time till delivery, and obstetrical outcomes with Hypovitaminosis D can also not observed. 


\section{CONFLICT OF INTEREST / DISCLOSURE}

No conflict of interest to be declared by any author involved in the research.

\section{ACKNOWLEDGEMENTS}

None.

\section{REFERENCES}

1. Ulkumen B, Silfeler D, Sofuoglu K, Silfeler I, Dayicioglu V. The incidence of preeclampsia in ICSI pregnancies. Pak J Med Sci. 2014;30(1):101-5.

2. Khawaja NP, Parveen A, Hussain U, Zahid B, Rehman R. Frequency and Obstetric outcome of hypertensive disorders of pregnancy. Hypertension. 2003;1551(1):4-34.

3. Karras S, Paschou SA, Kandaraki E, Anagnostis P, Annweiler C, Tarlatzis BC, Hollis BW, Grant WB, Goulis DG. Hypovitaminosis $D$ in pregnancy in the Mediterranean region: a systematic review. Eur J Clin Nutr. 2016;70(9):979-86.

4. Duley L, Henderson-Smart DJ, Meher S. Altered dietary salt for preventing pre-eclampsia, and its complications. The Cochrane Library 2005.

5. Bodnar LM, Catov JM, Simhan HN, Holick MF, Powers RW, Roberts JM. Maternal vitamin $D$ deficiency increases the risk of preeclampsia. J Clin Endocrinol Metab 2007;92(9):3517-22.

6. Holmes VA, Barnes MS, Alexander HD, McFaul P, Wallace JM. Vitamin $D$ deficiency and insufficiency in pregnant women: a longitudinal study. British Journal of Nutrition. 2009;102(06):87681.

7. Hyppönen E. Preventing vitamin D deficiency in pregnancyimportance for the mother and child. Annals of Nutrition and Metabolism. 2011;59(1):28-31.

8. Aghajafari F, Nagulesapillai T, Ronksley PE, Tough SC, O'Beirne M, Rabi DM. Association between maternal serum 25hydroxyvitamin D level and pregnancy and neonatal outcomes: systematic review and meta-analysis of observational studies. Bmj 2013;346:f1169.

9. Tabesh M, Salehi-Abargouei A, Tabesh M, Esmaillzadeh A. Maternal vitamin $D$ status and risk of pre-eclampsia: a systematic review and meta-analysis. J Clin Endocrinol Metab. 2013;98(8):3165-73.

10. Karateke A, Kurt RK, Baloğlu A. Relation of platelet distribution width (PDW) and platelet crit (PCT) to preeclampsia. Ginekol Pol. 2015;86(5):372-5.

11. Eiland E, Nzerue C, Faulkner M. Preeclampsia 2012. J Pregnancy. 2012;2012:586578.

12. American College of Obstetricians and Gynecologists; Task Force on Hypertension in Pregnancy. Hypertension in pregnancy. Report of the American College of Obstetricians and Gynecologists' Task Force on Hypertension in Pregnancy. Obstet Gynecol. 2013;122(5):1122-31.

13. Lambert G, Brichant J-F, Hartstein G, Bonhomme V, Dewandre P-Y. Preeclampsia: an update. Acta Anaesthesiol Belg 2014;65(4):137-49.

14. Steegers EA, von Dadelszen P, Duvekot JJ, Pijnenborg R. Preeclampsia. The Lancet. 2010;376(9741):631-44.

15. Merewood A, Mehta SD, Chen TC, Bauchner H, Holick MF, editors. Association between vitamin $D$ deficiency and primary cesarean section2013: Endocrine Society.
16. Powe CE, Seely EW, Rana S, Bhan I, Ecker J, Karumanchi SA, et al. First trimester vitamin $D$, vitamin $D$ binding protein, and subsequent preeclampsia. Hypertension. 2010;56(4):758-63.

17. Robinson CJ, Alanis MC, Wagner CL, Hollis BW, Johnson DD. Plasma 25-hydroxyvitamin $D$ levels in early-onset severe preeclampsia. Am J Obstet Gynecol. 2010;203(4):366.e1-6.

18. Wei S, Audibert F, Hidiroglou N, Sarafin K, Julien P, Wu Y, et al. Longitudinal vitamin $D$ status in pregnancy and the risk of preeclampsia. Br J Obstet Gynaecol. 2012;119(7):832-9.

19. Fernández-Alonso AM, Dionis-Sánchez EC, Chedraui $P$, González-Salmerón MD, Pérez-López FR. First-trimester maternal serum 25-hydroxyvitamin $D 3$ status and pregnancy outcome. Int J Gynecol Obstet. 2012;116(1):6-9.

20. Kaushal M, Magon N. Vitamin D in pregnancy: A metabolic outlook. Indian J Endocrinol Metab. 2013;17(1):76-82.

21. Halhali A, Tovar AR, Torres N, Bourges H, Garabedian M, Larrea F. Preeclampsia is associated with low circulating levels of insulin-like growth factor $I$ and 1,25-dihydroxyvitamin $D$ in maternal and umbilical cord compartments. J Clin Endocrinol Metab. 2000;85(5):1828-33.

\section{AUTHORSHIP CONTRIBUTION}

\begin{tabular}{|c|c|}
\hline $\begin{array}{l}\text { Dr. Mehwish llyas } \\
\text { Senior Registrar of Gynecology \& } \\
\text { Obstetrics, Lahore General Hospital, } \\
\text { Lahore Pakistan }\end{array}$ & Manuscript Writing \\
\hline $\begin{array}{l}\text { Dr. Sardar Muhammad Alfareed Zafar } \\
\text { Professor of Gynecology \& Obstetrics, } \\
\text { Lahore General Hospital, Lahore-Pakistan }\end{array}$ & Supervision \\
\hline $\begin{array}{l}\text { Dr. Maryam Javed } \\
\text { Senior Registrar of Gynecology \& } \\
\text { Obstetrics, Lahore General Hospital, } \\
\text { Lahore Pakistan }\end{array}$ & Data Collection \\
\hline $\begin{array}{l}\text { Dr. Muhammad Azeem Mughal } \\
\text { Senior Registrar, Kidney \& Transplantation, } \\
\text { Pakistan Kidney and Liver Institute Lahore } \\
\text { Pakistan }\end{array}$ & Statistical Analysis \\
\hline
\end{tabular}

